\begin{tabular}{llr} 
KULTURA & POLSKA A KADEMIA NAUK & ISSN 0023-5172 \\
i & KOMITET SOCJOLOGI & $2300-195 \mathrm{x}$ \\
SPOLCZENSTWO & $\begin{array}{l}\text { INSTYTUT STUDIÓW POLITYCZNYCH } \\
\text { 2020, nr 2 ANTROPOLOGIA ZAANGAŻOWANA }\end{array}$ & \\
\hline
\end{tabular}
$\begin{array}{llllllllllllll}A & R & T & Y & K & U & Ł & Y\end{array}$
I
$\begin{array}{llllllll}\mathrm{R} & \mathrm{O} & \mathrm{Z} & \mathrm{P} & \mathrm{R} & \mathrm{A} & \mathrm{W} & \mathrm{Y}\end{array}$

MONIKA BAER

University of Wroclaw

\title{
AT THE CROSSROADS OF MODERNITY: CRITICAL ANTHROPOLOGY IN CONTEMPORARY EUROPE
}

\section{INTRODUCTION}

Ghassan Hage (2012: 1) points out that since the turn of the century we have witnessed "an increasing reaffirmation of the critical anthropological tradition." While this might be true, at the same time specific connotations related to "critical anthropology" have been proliferating. It is understood both as a general type of research practice and as an analytical tool of distinct subdisciplines. A concept of critical anthropology has obviously its history, which can be traced back at least to the turn of the 1960s and the 1970s in works of such scholars as Stanley Diamond, Bob Scholte, Eric Wolf, Johannes Fabian or Talal Asad. Currently, however, it seems to operate as an empty signifier in Ernesto Laclau's sense, filled in with various meanings (more on these issues see: Baer 2020b). Despite this variety, anthropological critiques are usually envisioned as devices for designing imaginaries that would make a difference in the contemporary world (Hage 2012).

In this article I investigate potential of such critical interventions emerging in my own disciplinary practice since the mid-1990s till today. Drawing on an autoethnographic approach, I take personal experience 
as a prism that allows for analyzing broader research issues. The aim of pondering over a specific and contextual perspective is not only widening knowledge, but also engendering change (see Ellis, Adams, Bochner 2011). Consequently, in the last section of the paper I propose a form of anthropological engagement which seems to be effective for meeting this objective. The wider framework for my reasoning has been provided by the field of the political that materializes at intersections of diversified projects of modernity in contemporary Europe. In this context I focus mainly on the increasing polarization of European political scene, where rising politicization of "difference" related to gender, sexuality, race, nationality/ethnicity or religious beliefs brings various political Others (Verloo, Paternotte 2018: 1).

Following Chantal Mouffe (2005: 9), I take the political as "the dimension of antagonism," which is "constitutive of human societies." In contrast, I understand the politics as denoting "a set of practices and institutions through which order and organization is created, organizing human existence in the context of conflictuality provided by the political" (Mouffe 2005: 9). The political means therefore "the wider field of contingency and struggle that exceeds established regimes of politics" (Dzenovska, De Genova 2018: 3). It is rather this particular space than the sphere of institutionalized politics where possibilities for critical anthropological intervention may open up. Regarding "modernity," it is comprehended not as a historical period, but as a certain image "moving through the recent past and near future in a space that gauges modernity as an ethos already becoming historical" (Rabinow et al. 2007: 58). In this sense, varied images of modernity manage differently the politicized dimensions of "difference" and consequent ideas who or what the political Other might be.

\section{EUROPEAN MODERNITY AND ITS OTHERS}

The processes of shaping images of modernity in contemporary Europe have long and complicated history, which renounces simple categorizations (Delanty 2013). Yet, to outline specificity of the field of the political, in which critical anthropological interventions could be placed, I discuss basic types of such images unfolding as the aftermath of the Cold War. According to Gerard Delanty (2013: 245), "[t]he post-1989 period marked the beginning of a new era in the history of Europe producing new ideas of Europe and a major shift in modernity towards the inclusion of the post-national dimension. In this shift cosmopolitan tendencies can be found 
alongside contrary ones, which include nationalism, racism and xenophobia, and neoliberalism."

Projects of transnational modernity have been mainly promoted in connection to the European Union (EU), and embodied by a notion of "European citizenship" based on a (neo)liberal vision of "citizens as the rights-bearing agents who are equal before the law" (Dybska 2016: 21). This type of citizenship is recognized not only in legal, but also in cultural terms which acknowledge "the right to be different" (Rosaldo 1994: 57). The equality therefore means preventing and combating discrimination against distinct social groups defined by their respective characteristics. "Gender" or "sexual orientation" set such examples. Since the early 21 st century these ideas have been strictly related to concepts of human rights and tolerance understood as "a cultural and political marker of civilization as opposed to a specific conception of backwardness in the context of human rights protection" (Ammaturo 2017: 50). Accordingly, individuals and groups previously stigmatized as the Others by the majority of European societies have been currently replaced in this role by those who are not able and/or willing to adjust to the new European standards of cultural and legal equality.

Because the law offers instruments for individual and collective agency, it assumes a form of "politics by other means" (Wilson 2007: 355). On the one hand, it can "regulate and [...] constrain social, political, and economic action." On the other one, it may work for empowerment by providing frameworks for activities of the underprivileged social groups (Goodale 2017: 22-24). In this context both "human rights law" and "human rights talk" (Wilson 2007: 350) spread by European institutions have been used to discipline the Others lagging behind the "rational, enlightened, and modernizing" European core (Graham 2009: 296). Such discourses and practices have been therefore questioned by critical scholars and activists as deeply post/neocolonial and imperialist in nature (e.g. Massad 2007). But, "human rights law" and "human rights talk" may at the same time provide important tools to fight against social inequalities and exclusions. The categories of race, nationality/ethnicity, gender, sexuality, religious beliefs and any other grounds protected by the transnational European law constitute areas where citizens can strive to achieve the equality promised by the EU-related images of modernity (more on these issues see Baer 2020a).

Nevertheless, because "Europe does not exist in one certain way (Keinz, Lewicki 2019: 6)", the aforementioned models of modernity encounter other projects demanding modernity otherwise. The bulk of such 
projects evolves around concepts of "nation" and "nationalism." According to Delanty (2013: 258-59), post-1989 nationalisms in Europe are usually not "the product of long-run national identities," but rather "an expression of the crisis in social justice and solidarity." In this context nationalisms related to interests of nation-states and represented by mainstream political parties should be distinguished from populist and extremist nationalisms, which have been until recently situated at the peripheries of political life in the majority of European countries. While the former type "feeds into notions of nationality by the general population $[. .$.$] and$ has been compatible with Europeanization" in a form promoted by the European institutions, the latter one assumes frequently an anti-systemic character and has been to a wide extent defined by the logics of external and/or internal threats.

Obviously, both forms of nationalisms have been recently burgeoning all over Europe. But, even though more general trends in this regard can be traced, they should also be discussed in specific contexts in which they occur (Verloo, Paternotte 2018). In the literature on the subject nationalist tendencies have been traditionally associated rather with the countries of the post-Cold War European East than the West, which in turn have solidified the East-West division. I find such an approach highly problematic and tend to see links between the East and the West in relational terms, as "a product of crosscultural fertilization, encounters, dialogue and mediation rather than as self-contained and impermeable" (Delanty: 2013: 8). On the other hand, materialization of any "imagined reality" can still seem evident and real (Buchowski 2004: 895). Bearing this in mind, I believe that nationalisms in countries of Western and Central Eastern Europe (CEE) can be differentiated in view of a role played both by the EU and the EU-related gender equality, women's sexual rights, and LGBT rights in their respective projects of modernity.

Éric Fassin (2010: 515) notes that in the early 1990s in the most of EU countries nationalisms remained in opposition to the EU institutions. Currently, in France or the Netherlands the EU has been increasingly "presented as the best guarantee for the protection of national identities." Populist nationalist resentments have therefore shifted "from the cosmopolitan Eurocrats (above) to the non-European migrants (outside)." An important part of this shift has been adaptation and instrumentalization of gender and sexual democracy as defined by the EU-related projects of modernity. A couple of European nation-states have been vested with a status of "gay-friendly" to which the supposedly "homophobic" racialized Others pose a threat. Against this backdrop, the contemporary pro- 
jects of right-wing nationalist modernity do not necessarily oppose the EU with its ideas of gender equality, women's sexual rights, and LGBT rights. These are primarily Muslims and migrants from other locations than the EU Old Members States who are marked as the political Others. Accordingly, these projects contribute to such phenomena as "homonationalism" (Puar 2017) and "femonationalism" (Farris 2017), where the model European approach towards gender and sexuality is employed for xenophobic use. At the same time state-connected practices of "pinkwashing" may mask the very process and keep an image of the European (neo)liberal modernity largely untouched (Puar 2013: 337-38).

In contrast, in a couple of CEE countries, such as Hungary, Poland or Ukraine, the EU-related gender equality, women's sexual rights, and LGBT rights surface differently in the right-wing nationalist projects of modernity. The mainstream feminist and LGBT movements take the EU as "a repository of 'best practices' in the domain of gender equality and sexual politics" (Husakouskaya 2019: 81), and use "human rights rhetoric (including concepts such as tolerance, equality and diversity) in their attempt to counter rampant nationalism" (Husakouskaya 2019: 79). At the same time they try to negotiate their own national belonging (see e.g. Renkin 2015). On the other hand, in state-connected and other right-wing nationalist discourses gender equality, women's sexual rights, and LGBT rights are all seen as "Ebola from Brussels" (Korolczuk, Graff 2018), which compromises national sovereignty and/or takes over the nation-states from concerned citizens (Rawłuszko 2019). Consequently, in Poland, alongside "refugees," "Muslims," "Jews," or "Ukrainians," who meet criteria of the political Others in French or Dutch right-wing nationalist narratives, "feminists" and the "LGBT" are identified as such as well.

Moreover, the EU with its equality policies and appeal for acceptance of diversity has been cast as a foreign colonizer. Imposing gender equality, women's sexual rights, and LGBT rights by the means of not entirely democratic procedures substantiates this view (more on these issues see ibid.). This has allowed CEE right-wing nationalist projects of modernity to organize their ideas within the anticolonial frame. Unable to be rooted in actual colonial experience, the frame has still provided "a powerful signifier for humiliation that needs to be resisted" (Korolczuk, Graff 2018: 810). Consequently, the right-wing nationalist critiques target not only the Western "civilization of death," exemplified by reproductive and sexual rights, but also wider cultural, political and economic dimensions of the EU. In this case, however, the rhetoric of victimhood is usually combined with the rhetoric of superiority. Polish right-wing nationalists 
declare themselves to be "the last frontier of what they see as undamaged Christianity and true moral values in Europe," who are destined to defend European racial, national and cultural homogeneity (Korolczuk, Graff 2018: 811).

Yet, "anti-systemic" visions of modernity in contemporary Europe are by no means limited to the aforementioned cases. Both the EU policies in areas of gender equality, women's sexual rights, and LGBT rights as well as general cultural, political and economic framing of the EU, have been criticized by transnational alter-globalist and anarchist movements. Such initiatives can be seen as broader "expressions of discontent with inequality, precarity, corruption, and democratic deficit," and "connected by diffuse hopes for a global insurrection against neoliberal capitalism" (Dzenovska, De Genova 2018: 1). This type of endeavors advocates social justice for all those who are stigmatized as the Others both within the EU-related and right-wing nationalist projects of modernity. They speak up for individuals and groups underprivileged or dispossessed in view of the right of residence, economic status, access to educational and cultural resources, skin color, appearance, gender and sexual expressions and any other politicized dimensions of "difference," which are all seen as interconnected. Following direct democracy approach, the participants are not interested in joining institutionalized politics, but stick to various forms of grassroots social protest against diversely defined political regimes ${ }^{1}$.

Summing up, the discussed projects of modernity in contemporary Europe are all involved in multiple conflicts over politicized categories of difference related mainly to gender, sexuality, race, nationality/ethnicity or religious beliefs. This results in antagonized concepts of the political Others and contrasted ideas as to how the threats they pose should be managed. The consequent field of the political, marked with varied configurations of temporary alliances and dramatic struggles, appears complex, unstable and fragmented. At the same time, the fundamental polarization between "progressive" and "conservative" positions emerge, even though its particular forms may unfold in myriad ways. In what follows, I discuss possibilities of critical anthropological engagement in so conceived

\footnotetext{
${ }^{1}$ This stance is exemplified, alongside others, by queer movements built on ideas of relational and performative nature of gender and sexuality. Binary thinking, stable identity categories, and any forms of essentialized "difference" are accordingly seen as symbolically violent tools of othering. The queer agenda is therefore set against the EU-related mainstream feminist and LGBT initiatives even though queer activists recognize the right of all non-heteronormative persons to live the life of their choice (more on these issues see Baer 2020a).
} 
space as exemplified by my own disciplinary practice based in contemporary Poland.

\section{CRITICAL ANTHROPOLOGY AS A POLITICAL PROJECT}

From the mid-1990s till the end of first decade of 21st century my personal understanding of critical anthropology was in many ways determined by activism oriented gender and queer studies ${ }^{2}$. But, it was also marked by epistemological and methodological shifts in social sciences dating back to the turn of the 1970s and the 1980s. On the one hand, inspirations linked to philosophy of critical humanism and theory of practice recognized human acting subjects as central figures of social life. "Produced" by specific social systems, the subjects could at the same time disrupt or remodel these systems through their practices (Ortner 1984: 144-160). On the other hand, the "postmodern turn" brought idea of defamiliarization, that is, a strategy of juxtaposing of different contexts of the contemporary world in order to expose all "ideologies in action" (Marcus, Fisher 1999: 156-159). Rooted in such premises, critical anthropology may combine ethnographic details with theoretical insights to "cut against the grain by unveiling how culture makes us think that, in fact, socially constructed meanings and hierarchies are 'natural', and how existing relations of power and ideology are legitimized" (Buchowski 2001: 19). It therefore reveals agency of these social actors who are customarily "excluded from grand narratives and mainstream ideology" (Buchowski 2001: 20).

In line with the above approach, I conceived anthropological contribution to the field of the political as a critical participation in the academic activist debate conducted in a frame of gender and queer studies. The gender and queer studies has developed in Poland on a wider scale as a consequence of political mobilization of feminist and LGBT movements. Since the early 21 st century this mobilization has been largely based on a cultural and legal model of European integration (see e.g. Rawłuszko 2019). Consequently, the EU-related projects of modernity, with its (neo)liberal concept of European citizenship, including gender equality, women's sexual rights, and LGBT rights, have defined Polish activism in many important ways. The feminist movements have been promoting equalization of opportunities for men and women in public spheres, improvement in the health of women and women's reproductive

2 In Poland a label "queer studies" pertains frequently to all research on non-heteronormative genders/sexualities, including conventional LGBT studies. 
rights, and counteracting violence against women. On the other hand, the LGBT movements have been focusing on cultural and legal sexual citizenship with purpose of increasing public visibility and legal protection of homosexual and trans* persons ${ }^{3}$.

In the broader field of the political I did support (and I am still supporting) so defined political agenda as contradicting local versions of right-wing nationalist and other "conservative" images of modernity. Yet, in academic settings I used critical anthropology to problematize premises on which political involvement of gender and queer studies had been built. Even though my own political and epistemological positioning was much closer to anarchist queer projects than to the EU-related feminist and LGBT ones, I criticized both political stances. In this context, I denounced literal application of Western-modelled political strategies as ineffective in a postsocialist environment; exposed unjustified generalizations which ignored specificities of local entanglements; and unveiled symbolic violence intrinsic to all identity politics. By privileging "critically informed ethnography" as a tool for grasping "differences, complexities, and contradictions" (Valentine 2003: 46), I was at the same time unable to see my own narratives the way they really were: another academic activist discourse in which "textual complexity" embodied "a moral ideal of plurality" (Mutman 2006: 160).

Despite my deep conviction that the proposed anthropological perspective would increase the awareness of problems brought by feminist, LGBT, and queer projects, and thereby would improve their political efficiency, these expectations could not come true. Because conventionally understood activism requires certainty about political subjects and aims, the approach destabilizing all identities and strategies at hand was not particularly helpful. The academic activist debates of that time were obviously differentiated in view of premises on which political practice should have been based and linked either to the EU-related or more anarchist projects. But, considering relations between LGBT and queer groups in Poland Tomasz Basiuk (2012: 76) notes that they represented "two mod-

\footnotetext{
${ }^{3}$ In the course of the last two decades not much has changed. For instance, since 1993 Poland has had one of the most restricted anti-abortion laws in Europe. While the LGBT movements have managed to improve social visibility of their political cause, they have failed in attempts to introduce legal protective measures. Since 2015, when the right-wing nationalist Law and Justice party took over the government from the centrist predecessors, political, legal and financial measures aimed at preventing and combating social exclusions, inequalities and discrimination in view of gender, sexuality, race, nationality/ethnicity, religious beliefs, and disability, have been steadily diminished.
} 
alities of one movement which raise[d] disagreements, but not serious divergence." In fact, they all, in one way or another, supported (neo)liberal gender and sexual democracy.

In contrast, critical ideas that have been in the recent decade emerging in Polish anthropology appear much more consistent with politically oriented gender and queer studies than my own stance. They form, to a greater or lesser extent, a kind of "engaged anthropology" where "the field-based practice of values" aims at "the emancipation of research subjects" (Červinková 2012: 27). This brand of anthropological praxis does not therefore question specific political categories, but rather points to realities which generate social exclusions and inequalities, and searches for possible solutions. Yet, I personally find it not sufficiently self-reflexive (more on these issues see Baer 2019).

\section{CRITICAL ANTHROPOLOGY AS AN ACADEMIC PROJECT}

In my case the discussed anthropological experience in the field of the political have resulted in reformulation of a concept of critical anthropology, and a shift towards a more politically distanced academic position. The critical character of my activity has not obviously allowed me to depart from political engagement altogether, but has brought a new perception of what activist dimensions of scholarly work might be. The approach I have consequently developed builds on some elements of "anthropology of the contemporary" by Paul Rabinow (2003), "para-ethnography" by George'a E. Marcus (2007) and "ethnography in late industrialism" by Kim Fortun (2012).

First and foremost, this new project advocates problematization of discourses, practices and phenomena forming the analyzed field of the political, including critical anthropology itself. They are all taken as "emergent assemblages" (Rabinow 2003: 56), whose emergence and effects need to be documented, analyzed, named and defined. To proceed with this task, anthropologists need to keep a "certain critical distance, an adjacency, untimeliness" as opposed to "being 'timely,' 'accessible,' 'instructive"' (Rabinow et al. 2008: 58-59). In this way they can mark anthropological distinctiveness "in a field full of competing and overlapping discourses and related purposes and projects" (Rabinow et al. 2008: 65). While being "untimely" does not deny actual violence, marginalization or injustice, it also requires reflexivity to be a vital part of both activism and anthropology.

Secondly, all actants contributing to the field of the political become "epistemic partners" of the contemporary world, which is seen as 
a product of nested systems involved in multiple interactions and reconfigured by numerous scales, variables and forces (Fortun 2012: 451-52). Connected by "collaborative imaginaries," "epistemic partners ally complicitly in mutual awareness of motivated interest in a 'third' elsewhere -an object of curiosity, fear, anxiety, a speculation about agency that is elsewhere but is present in many important ways" (Marcus 2007: 7). People's lifeworlds appear thus to extend in many different directions. Seen through this prism, every project in the field of the political resembles a contraption where the nodes and rhizomes can be traced, but cannot be linked to form a whole. On the contrary, any attempt to analytically introduce logics and order brings solely another contraption. Yet, the discussed ideas do take into account that even though the actual wholes do not exist, there are still "vectors of power and force lines" which cannot be controlled, and a "grid of connections" which are not purely of mental nature (Rabinow et al. 2008: 77).

Last, but not least, ethnography is conceived here as an experimental system "that generates surprises" (Fortun 2012: 451). Embedded in a Derridian concept of futur antérieur, it is designed to think about a future which "inhabits the present, yet it also has not yet come" (Fortun 2012: 450). Ethnography operates therefore as performance art: "create[s] a space for deliberation, for worrying through, for creativity, [...] [for] encounters" (Fortun 2012: 453). But, the multiplicity of voices does not enact a pluralist utopia where everyone is given "a chance to speak, as a matter of fairness" (Fortun 2012: 453). The goal of ethnography is "performing the labor of difference," that is, "being open to intervention and foreigners (ibid.)" to avoid "the teleological overtones of activism as usual" (Fortun 2012: 450).

The discussed model of critical anthropology seems to provide adequate tools for multidimensional problematization of the aforementioned projects of European modernity, and their materializations in the field of the political in Poland and beyond. Yet, my personal application of its premises have been so far rather modest and limited to academic settings. Despite this fact, it allows me to formulate a couple of strengths and weaknesses of the proposed approach in terms of its actual potential for social/political change. In the next sections I discuss these issues as exemplified by the ethnographically-based research project conducted in the Dobrzeń Wielki commune in Opole Silesia in southern Poland ${ }^{4}$.

4 The fieldwork research took place between January 2015 and November 2018 and formed a part of a team research project "Conflict, Tension and Cooperation: A Case Study of 
The project concerned mainly relationships between the Opole Power Station located in the commune area and the local community in view of the ongoing construction of the fifth and sixth blocks of the power plant. The investment comprised then one of the largest developments in the energy sector in Europe. With time my own focus shifted, however, towards agency of female residents of the Dobrzeń Wielki commune. This was mostly because it problematized in many important ways opinions on Opole Silesia given by both popular and scientific literature. Whereas discussions on demographic situation, family relations, migration, or the generally understood "Silesianity" usually conceived the region in terms of "collapse" or "disintegration," in my own publications I was highlighting women's involvement in various social initiatives of different scales and scopes (Baer 2018a, 2018b). The activist dimension of my work consisted largely in the unfolding of narratives which destabilized the distinction between the "dark anthropology" and "anthropology of the good" (Ortner 2016). I discussed the conditions shaping such experiences of modernity over which my interlocutors had little or no influence. I also accounted for the local and supralocal manifestations of the capillary power of governmentality in Michel Foucault's sense. Yet, I was at the same time analyzing grassroots forms of activities and resistance rooted in politics and ethics of hope, which fueled aspirations towards a "good life."

According to Arjun Appadurai (2013: 293), "hope is the political counterpart of the work of imagination. For it is only through some sort of politics of hope that any society or group can envisage a journey to desirable change in the state of things." Effectively, the "ethics of probability," which focuses on risks and dangers and subsequent management and surveillance, encounters the "ethics of possibility." The latter is seen as "ways of thinking, feeling, and acting that increase the horizons of hope, [...] that widen the field of informed, creative and critical citizenship" (Appadurai 2013: 295). By showing grassroots manifestations of "tectonic struggles between these two ethics" (Appadurai (2013: 295), my critical anthropological analyses based on the fieldwork research in the Dobrzen Wielki commune provided imaginaries of the social/political change that allows for better future.

Nonetheless, although such form of critical anthropology undoubtedly contributes to the analyzed field of the political, this contribution is quite

Mutual Impact between Opole Power Station and the Community of Dobrzeń Wielki," funded by the National Science Center (grant number 2013/11/b/HS3/03895), and conducted at the University of Wroclaw with Petr Skalník as the Principal Investigator. 
limited in its form and scope. Firstly, as in my previous projects in the areas of interdisciplinary gender and queer studies, the current anthropological practice sticks still to convention of the educator conveying certain information to the educated. The aim of spreading anthropological knowledge is to stimulate critical reflection and to create a situation of debate, which can and often does find a practical outlet (more on these issues see Červinková 2019). Yet, acknowledging the impact of critical anthropological insights, even when confirmed by empirical examples, should not overshadow the imbalance in exchanges associated with the privileged position of the anthropologist, who determines terms and frames of the exchange.

Secondly, this type of anthropological practice is first and foremost linked to academic spaces. When its message reaches outside the academia, then it reaches the audience who is-at least potentially-already somewhat open to this kind of message. It is therefore not capable of making a difference on a larger scale. In fact, "the labor of difference" as understood by Fortun (2012) or the related "dynamic agonism" described by Mouffe (2005) can only be performed if participants are interested in having a discussion. This is due to the requirement of mutual acceptance of the coexistence of conflicting parties. Only then can a dispute become a form of "taming" the relation of conflict with concurrent awareness that a "rational consensus" is not possible to attain. Yet, it is difficult to imagine in a case of polarized versions of European modernity and their translations into local contexts exemplified by the field of the political in contemporary Poland. The strategies of creating political Others employed by proponents of modernity related to the EU or alter-globalist and anarchist in nature, as well as that linked to right-wing nationalism, do not represent a situation of agonism but of classic antagonism. A desired way of conflict resolution is the elimination of one of the opposing parties (more on these issues see Mouffe 2005: 8-34).

This does not mean, however, that in the Polish field of the political examples of "the labor of difference" cannot be found. Excepting a type of communication which accompanies LGBT marches of equality or far-right celebrations of national holidays, and involves the exchange of hateful slogans and epithets, agonistic alternatives may be also encountered. But, they are usually limited to conventionally understood intelligentsia (see e.g. Sroczyński, Terlikowski 2019). It should be therefore considered how social scientists could facilitate an inclusion of Gramscian "organic intellectuals" into such "labor of difference." In other words, the question I am trying to answer in the last part of this paper is: how critical anthropology, 
based on the discussed ontological, epistemological, and methodological premises, could be transformed into a social/political praxis capable of undermining antagonistic relations between the political Others intrinsic to contemporary European visions of modernity.

\section{CRITICAL ANTHROPOLOGY AS EMOTIONAL PRAXIS}

Edward Said (1989: 216) points out that just as any other perspective in the contemporary world, anthropological critique does not remain "outside the actuality of relationships [...] between different Others. [...] [W]e are so to speak of the connections, not outside and beyond them" (Owczarzak 2009: 12). It is precisely as one of the actants in the field of the political defined by the European ideas of modernity that critical anthropology can work to inspire social/political change.

An option in this respect arises from the aforementioned research in the Dobrzeń Wielki commune, which was conducted in a situation of first anticipated and then realized takeover of a part of the commune along with the Opole Power Station by the nearby city of Opole. A study of social protests triggered by this event exposed not only the driving force of emotions in the field of the political, but also their dynamic responses to changing circumstances. The political became an arena where more or less stable forms of affective togetherness of various temporal and spatial scales were constantly (re)shaping social realities (more on these issues see Baer 2018b). I therefore believe that these are trends brought by the "affective turn" in social sciences in the mid-1980s where tools should be sought to problematize antagonisms of the field of the political in question.

Pointing to the psychological, social, and material dimension of emotions, researchers show that they create both acting subjects and their realities. Sarah Ahmed (2014: 10) notes that "it is through emotions, or how we respond to objects and others, that surfaces or boundaries are made: the 'I' and the 'we' are shaped by, and even take the shape of, contact with others." Furthermore, emotions provide "devices for identifying what comes to matter to people in diverse historical, cultural, and political contexts" (Lutz 2017: 181), not only individually, but also collectively. Since such an approach to emotions reveals that they are strongly politicized, it allows for subverting these views on politics and the political, which relegate many aspects of modernity to the spheres of the personal and the private (Svašek 2008).

Looking at emotions through the prism of "affective economies" (Ahmed 2014: 44-46), that is, as at a form of circulating capital that pro- 
duces collective subjects, may help explain why conventional educational strategies are not particularly effective in the field of the political ${ }^{5}$. Given that emotions comprise the important driving force in/of such fields, the tools for undermining social configurations pertaining to them must rely on a logic similar to the one defining political Others and ensuing conflictuality. In other words, to contribute to social/political change, critical anthropology should consider or even make use of emotions.

One of the inspirations emerges from the classic concept of tactical humanism proposed by Lila Abu-Lughod (1991) as a part of her "writing against culture" project, whose objective was to break with a figure of the cultural Other. Her reasoning grows from the awareness that the European philosophy of humanism, based on Enlightenment universalism, has been completely discredited in the contemporary world. Yet, it remains an equality discourse of the significant moral force. The discussed ambivalent workings of "human rights" in contemporary Europe set an example. Consequently, "tactical humanism" can be seen as a local language which, instead of maintaining, acts against various relations of power. Abu-Lughod takes it primarily as a writing convention with a purpose to tell stories about particular people living in a particular place and time. Her goal is to demonstrate that even though at the first glance lives of different people seem completely different, in certain aspects they are in fact similar. These similarities become most apparent in spheres of human emotions (Abu-Lughod 1991: 157-160).

It is this ethical premise which can provide the starting point for critical anthropological praxis to open up Appadurai's "horizons of hope." To this end, the praxis needs to allow antagonized individuals and groups to discern the interstices of familiarity, and therefore making "the labor of difference" possible. In this context, the contribution of anthropology (as well as of other academic or activist circles) could consist in creating conditions, situations or spaces conducive to bringing this familiarity to the fore. Effectively, this would show that political Others may have things in common as human beings. Examples of grassroots initiatives, frequently based on knowledge obtained through ethnographic tools, which turn such ideas into practice are numerous (see e.g. Bloch, this volume, pp. 71-97). To shed light on the potential of the proposed form of critical an-

${ }^{5}$ Although contrary to a popular belief, the sphere of politics is not only defined by rational, but also by emotional calculations, the analyzed anthropological strategies for social/political change apply only to the field of the political. It is this area where the work of emotions seems to have the greatest impact. 
thropological engagement, I scrutinize below two cases presented at the International Union of Anthropological and Ethnological Sciences inter-congress held in Poznań, Poland in August 2019.

The first case was discussed by Marek Sancho Höhne (2019) from European University Viadrina Frankfurt (Oder), who conducts research on the trans* movements in Germany, while at the same time being a trans* activist themselves. In the latter context, they are involved in projects implemented in small towns of the German part of West Pomerania, where extreme right-wing and/or neo-fascist groups and sympathies are strong. Part of this venture was a mobile exhibition displaying non-heteronormative people from these areas in public space, in both historical and contemporary contexts. The visitors could see photos or listen to stories of persons who were close to them, at least spatially (see also Höhne, Woopen 2018). This situation triggered emotions thanks to which within this specific field of the political the Other was becoming, in a sense, one's own. Höhne believes that this type of initiatives, based on participatory knowledge, but generated through the use of academic tools, is an effective way of changing individual approaches to "sexual minorities," even if only at the micro level.

The second case was presented by Esther Hertzog (2019) from Zefat Academic College and pertained to grassroots activities for peace in Israel, animated by Hertzog herself and Palestinian activist Ibtisam Mahmeed. The initiative of these two women led to cooperation and often friendship between people of local Jewish and Muslim communities. It also activated women from those communities who at the local level managed to carry out several legislative changes important in light of their needs, or to introduce practical solutions facilitating their daily lives. All of these created a "women's space" for performing "the labor of difference," in many ways conditioned by the ongoing war between the State of Israel and the Palestinians. But, Hertzog's attitude to this story was marked by clear skepticism. In her view such grassroots feminist initiatives brings only "delightful pictures" 6 , not "a big impact" of a larger political scale.

The contradictory opinions of both scholars as to actual effects of their respective projects shows that the answer to the question whether critical anthropology as emotional praxis is able to work for social/political change depends on how we formulate our goals. I find this particularly vital for my own concluding remarks.

6 21see, Peace Activist Ibtisam Mahmeed and Esther Hertzog, 2018, (https://www.youtube. $\mathrm{com} /$ watch? $\mathrm{v}=1$ Y8E6aCMM-s [accessed: 09.09.2019]). 


\section{CONCLUSIONS}

In the light of the discussed issues, it seems that the anthropological response to politicizing "difference" in contemporary Europe-in view of gender, sexuality, race, nationality/ethnicity or religious beliefs-which leads to proliferation and/or polarization of political Others, should not necessarily refer to conventional educational methods. Bringing emotions and human affective agency to the fore seems to be more useful. A version of critical anthropology that I have currently adopted, when linked with a concept of "tactical humanism," may favor this. It is because this lets us think about situations or spaces where antagonistic values, attitudes, and needs can wrangle, yet simultaneously "taming" each other's Otherness by unveiling shared experiences and feelings.

But, I also believe that an assumption that anthropological critique may have a broader scope, an impact on "society" or even its certain sectors, appears rather utopian. Some degree of success seems attainable only if we admit that critical anthropology allows us to act for social/political change in particular locations at the micro level. Today I would therefore envision the possibility of anthropological engagement in the field of the political through the metaphor of "bubbling lakes," by means of which one of the interlocutors of Magdalena Grabowska (2009) once defined the specificity of Polish feminism. It definitely exists and flourishes, but takes various forms, and its actual potential for making a difference should not be overestimated.

Taking all these into account, in conclusion it may be worthwhile to let founding mothers and fathers of critical anthropology have their say, even if only as a paraphrase. Closing his classical essay entitled Dilemmas of Critical Anthropology Johannes Fabian (2000: 264) urges us to remember that "we will always be liable to be seen (correctly) as old [preachers] in a new guise as long as we understand critical, emancipatory anthropology as doing our critique to [teach] them [...]. Who are we to ['teach'] them? We need critique to [...] [teach] ourselves. The catch is, of course, that 'ourselves' ought to be them as well as us."

\section{REFERENCES}

Abu-Lughod, Lila. 1991. "Writing against Culture." In: Richard G. Fox (ed.). Recapturing Anthropology: Working in the Present. Santa Fe: School of American Research Press.

Ahmed, Sarah. 2014. The Cultural Politics of Emotion: Second Edition. Edinburgh: Edinburgh University Press. 
Ammaturo, Francesca Romana. 2017. European Sexual Citizenship: Human Rights, Bodies and Identities. London: Palgrave Macmillan.

Appadurai, Arjun. 2013. The Future as Cultural Fact: Essays on the Global Condition. London: Verso.

Baer, Monika. 2018a. "Social Activity of Women in the Dobrzeń Wielki Commune in Light of Anthropological Critique." In: Petr Skalník (ed.). Mutual Impact: Conflict, Tension and Cooperation in Opole Silesia. Wrocław: Uniwersytet Wrocławski.

Baer, Monika. 2018b. “'No bo tym się żyło': Podział gminy Dobrzeń Wielki w narracjach jej mieszkańców”. Prace Etnograficzne 46(4): 111-133 (DOI: 10.4467/22999558.PE.18.022. 10165).

Baer, Monika. 2019. "Anthropology and Gender/Queer Studies in Contemporary Poland: A Personally Situated View.” In: Michał Buchowski (ed.). Twilight Zone Anthropology: A Voice from Poland, Herefordshire: Sean Kingston Publishing.

Baer, Monika. 2020a. "Europeanization on the Move: The LGBT/Q Activist Projects in Contemporary Poland." Intersections: East European Journal of Society and Politics 6(3).

Baer, Monika. 2020b. „Antropologia krytyczna jako ustrojstwo: Subiektywne refleksje z autoetnograficzną mikrohistorią w tle.” In: Anna Brzezińska, Wojciech Dohnal (eds.). Myśli — pasje - działania: Sto lat etnologii uniwersyteckiej w Poznaniu. Poznań: Wydawnictwo Instytutu im. Oskara Kolberga.

Basiuk, Tomasz. 2012. „Coming out a queer: Kontekst amerykański, kontekst polski.” In: Monika Kłosowska, Mariusz Drozdowski, Agata Stasińska (eds.). Strategie queer: Od teorii do praktyki. Warszawa: Difin.

Buchowski, Michał. 2001. Rethinking Transformation. Poznań: Wydawnictwo Humaniora.

Buchowski, Michał. 2004. "European Integration and the Question of National Identity: Fear and Its Consequences." The Polish Review 49(3): 891-901.

Červinková, Hana. 2012. "Feminist Theory, Anthropology and Engagement." Zeszyty Etnologii Wroctawskiej 1(16): 25-36.

Červinková, Hana. 2019. "Nauczanie i uczenie się antropologii w edukacji nauczycieli.” In: Hana Červinková (ed.). Antropologia i edukacja: Etnograficzne badania edukacyjne w tradycji amerykańskiej. Wrocław: Wydawnictwo Naukowe Dolnośląskiej Szkoły Wyższej.

Delanty, Gerard. 2013. Formations of European Modernity: A Historical and Political Sociology of Europe. London: Palgrave Macmillan.

Dybska, Aneta. 2016. Regeneration, Citizenship, and Justice in the American City since the 1970s. Frankfurt am Main: Peter Lang.

Dzenovska, Dace, Nicholas De Genova. 2018. "Introduction: Desire for the Political in the Aftermath of the Cold War." Focaal-Journal of Global and Historical Anthropology 80: 1-15 (DOI: 10.3167/fcl.2018.800101).

Ellis, Carolyn, Tony E. Adams, Arthur P. Bochner. 2011. "Autoethnography: An Overview." Forum: Qualitative Social Research 12(1), art. 10 (DOI: 10.17169/fqs-12.1.1589).

Fabian, Johannes. 2000. "Dilemmas of Critical Anthropology.” In: Johannes Fabian. Time and the Work of Anthropology: Critical Essays 1971-1991. Amsterdam: Harwood Academic Publishers.

Farris, Sarah. 2017. In the Name of Women's Rights: The Rise of Femonationalism. Durham: Duke University Press. 
Fassin, Éric. 2010. "Identities and Transnational Intimacies: Sexual Democracy and the Politics of Immigration in Europe." Public Culture 22(3): 507-529 (DOI: 10.1215/089923 63-2010-007).

Fortun, Kim. 2012. "Ethnography in Late Industrialism.” Cultural Anthropology 27(3): 446-464 (DOI: 10.1111/j.1548-1360.2012.01153.x).

Goodale, Mark. 2017. Anthropology and Law: A Critical Introduction. New York: New York University Press.

Grabowska, Magdalena. 2009. "Pomiędzy Wschodem i Zachodem: Problem tożsamości polskiego feminizmu w kontekście współczesnych debat.” In: Bogusława Budrowska (ed.). Kobiety, feminizm, demokracja. Warszawa: IFiS PAN.

Graham, Mark. 2009. "LGBT Rights in the European Union: A Queer Affair?” In: Ellen Lewin, William L. Leap (eds.). Out in Public: Reinventing Lesbian/Gay Anthropology in a Globalizing World. Malden, MA: Wiley-Blackwell.

Hage, Ghassan. 2012. "Critical Anthropological Thought and the Radical Political Imaginary Today." Critique of Anthropology 32(3): 285-308 (DOI: 10.1177/0308275X12449105).

Hertzog, Esther. 2019. Ibtisam and Myself: A Story of Love and Cooperation on the Background of Implicit Hostility, paper presented at the IUAES Inter-Congress "World Solidarities", 27-31 August, Poznań.

Höhne, Marek Sancho. 2019, Solidarity and Difference in Current Trans* Communities, paper presented at the IUAES Inter-Congress "World Solidarities", 27-31 August, Poznań.

Höhne, Marek Sancho, Clara Woopen. 2018. "Lola für Demokratie in Mecklenburg-Vorpommern - geschlechterreflektierte Arbeit für eine demokratische Kultur.” Newsletter für Engagement und Partizipation in Deutschland 23: 1-4.

Husakouskaya, Nadzeya. 2019. "Geopolitical Transition of the European Body in Ukraine." Anthropological Journal of European Cultures 28(1): 79-83 (DOI: 10.3167/ajec.2019.2801 10).

Keinz, Anika, Paweł Lewicki. 2019. "Who Embodies Europe? Explorations into the Construction of European Bodies." Anthropological Journal of European Cultures 28(1): 7-24 (DOI: 10.3167/ajec.2019.280104).

Korolczuk, Elżbieta, Agnieszka Graff. 2018. "Gender as 'Ebola from Brussels': The Anti-colonial Frame and the Rise of Illiberal Populism." Signs: Journal of Women in Culture and Society 43(4): 797-821 (DOI: 10.1086/696691).

Lutz, Catherine. 2017. "What Matters." Cultural Anthropology 32 (3): 181-191 (DOI: 10.14506 /ca32.2.02).

Massad, Joseph A. 2007. Desiring Arabs. Chicago: The University of Chicago Press.

Marcus, George E. 2007. “Collaborative Imaginaries.” Taiwan Journal of Anthropology 5(1): 1-17 .

Marcus, George E., Michael M. J. Fischer, 1999, Anthropology as Cultural Critique: An Experimental Moment in the Human Sciences: Second Edition. Chicago: The University of Chicago Press.

Mouffe, Chantal. 2005. On the Political: Thinking in Action. London: Routledge.

Mutman, Mahmut. 2006. "Writing Culture: Postmodernism and Ethnography." Anthropological Theory 6(2): 153-178 (DOI: 10.1177/1463499606065033).

Ortner, Sherry B. 1984. "Theory in Anthropology since the Sixties." Comparative Studies in Society and History 26(1): 126-166 (DOI: 10.1017/s0010417500010811). 
Ortner, Sherry B. 2016. "Dark Anthropology and Its Others: Theory since the Eighties." HAU: Journal of Ethnographic Theory 6(1) (DOI: 10.14318/hau6.1.004).

Owczarzak, Jill. 2009. "Introduction: Postcolonial Studies and Postsocialism in Eastern Europe.” Focaal-European Journal of Anthropology 53: 3-19 (DOI: 10.3167/fcl.2009.53010 10).

Puar, Jasbir. 2007. Terrorist Assemblages: Homonationalism in Queer Times. Durham: Duke University Press.

Puar, Jasbir. 2013. "Rethinking Homonationalism." International Journal of Middle East Studies 45(2): 336-339 (DOI:10.1017/S002074381300007X).

Rabinow, Paul. 2003. Anthropos Today: Reflections on Modern Equipment. Princeton: Princeton University Press.

Rabinow, Paul, George E. Marcus, James D. Faubion, Tobias Rees. 2008. Designs for an Anthropology of the Contemporary. Durham: Duke University Press.

Rawłuszko, Marta. 2019. "And If the Opponents of Gender Ideology Are Right? Gender Politics, Europeanization, and the Democratic Deficit." Politics and Gender (DOI: 10.1017/ S1743923X19000576).

Renkin, Hadley Z. 2015. "Perverse Frictions: Pride, Dignity, and the Budapest LGBT March." Ethnos: Journal of Anthropology 80(3): 409-432 (DOI: 10.1080/00141844.2013.879197).

Rosaldo, Renato. 1994. "Cultural Citizenship in San Jose, California." PoLAR: Political and Legal Anthropology Review 17(2): 57-64 (DOI: 10.1525/pol.1994.17.2.57).

Sroczyński, Grzegorz, Tomasz Terlikowski. 2019. "PiS to nie są konserwatyści. Grają rolę obyczajowej prawicy, ale grzeje ich tylko władza" (http://wiadomosci.gazeta.pl/wiadomos ci/7,114883,25172442,terlikowski-pis-to-nie-sa-konserwatysci-graja-role-obyczajowej. html [09.09.2019]).

Svašek, Maruška. 2008. "Introduction: Postsocialism and the Politics of Emotions." In: Maruška Svašek (ed.). Postsocialism: Politics and Emotions in Central and Eastern Europe. New York: Berghahn Books.

Valentine, David. 2003. “'The Calculus of Pain': Violence, Anthropological Ethics, and the Category Transgender." Ethnos: Journal of Anthropology 68(1): 27-48 (DOI: 10.1080/0014 184032000060353).

Verloo, Mieke, David Paternotte. 2018. “The Feminist Project under Threat in Europe.” Politics and Governance 6(3): 1-5 (DOI: 10.17645/pag.v6i3.1736).

Wilson, Richard A. 2007. "Conclusion: Tyrannosaurus Lex: The Anthropology of Human Rights and Transnational Law.” In: Mark Goodale. Sally E. Merry (eds.). The Practice of Human Rights: Tracking Law Between the Global and the Local. Cambridge: Cambridge University Press.

\section{Abstract}

This article addresses anthropological involvement in a political sphere constituted by the politicization of "difference" in European modernity projects, and in this context, especially conflicts related to gender, sexuality, race, nationality/ethnicity, or religious beliefs, which result in visions of antagonized, political Others. The author refers to the autoethnographic perspective and discusses her own disciplinary practices from the mid-nineties to today, pointing to the positive and 
negative sides of those practices. She first discusses the idea of critical anthropology as an element of academic activist debates within gender and queer studies. Then she looks at a more academic position, which makes critical anthropology into an instrument for creating images of a better future. Ultimately, she advocates a vision of critical anthropology that focuses on affective agency, thanks to which conflicting factions may perceive shared experiences and feelings. She does not assume that this kind of critical engagement is capable of bringing about broader social or political change, but believes it could make a contribution to acceptance of the Other on the micro-scale.

key words: critical anthropology, modernity, Otherness, social/political change

\title{
NA ROZDROŻACH NOWOCZESNOŚCI: ANTROPOLOGIA KRYTYCZNA WE WSPÓŁCZESNEJ EUROPIE
}

\author{
Monika Baer \\ (Uniwersytet Wrocławski)
}

\section{Abstrakt}

W artykule zostają podjęte kwestie możliwości zaangażowania antropologicznego w polu politycznego ukonstytuowanym poprzez polityzację „różnicy” w europejskich projektach nowoczesnościa, a w tym kontekście zawłaszcza konflikty związane z płcią, seksualnością, rasą, narodowością/etnicznością czy przekonaniami religijnymi, których efektem są wizje zantagonizowanych politycznych Innych. Autorka odwołuje się do perspektywy autoetnograficznej i omawia własne praktyki dyscyplinarne stosowane od połowy lat dziewięćdziesiątych do dziś, wskazując na ich dobre i złe strony. Najpierw zajmuje się ideą antropologii krytycznej jako elementem akademickich debat aktywistycznych w przestrzeniach studiów gender i queer. Następnie przygląda się stanowisku o charakterze bardziej akademickim, które sytuuje antropologię krytyczną $\mathrm{w}$ roli narzędzia służącego kreowaniu wyobrażeń lepszej przyszłości. Ostatecznie opowiada się za wizją antropologii krytycznej w centrum zainteresowań stawiającej sprawczość afektywną, dzięki której skonfliktowane frakcje mogą dostrzec podzielane doświadczenia i uczucia. Nie zakłada, że ten rodzaj zaangażowania krytycznego jest w stanie przynieść zmiany społeczne/polityczne o szerszym zasięgu, sądzi jednak, iż może on wnieść wkład w oswajanie Inności w mikroskali.

stowa kluczowe: antropologia krytyczna, nowoczesność, Inność, zmiana społeczna/polityczna 